\title{
Partisipasi Masyarakat dalam Pengelolaan Dana Desa: Kasus di Kabupaten Lima Puluh Kota, Provinsi Sumatera Barat
}

\author{
Fatizah Rahmi ${ }^{1}$, Asrinaldi ${ }^{2}$, Indah Adi Putri ${ }^{3}$ \\ Diserahkan: 12 Oktober 2021 | Diterima: 5 Januari 2022 | Diterbitkan: 18 Januari 2022
}

\begin{abstract}
Abstrak
Penelitian ini berangkat dari konsep pembangunan yang berbasis desentralisasi, yaitu pergeseran arah pembangunan top-down menjadi bottom-up menuntut pembangunan yang berpusat dari masyarakat, seperti halnya dalam partisipasi pengelolaan dana desa. Partisipasi masyarakat dalam pengelolaan dana desa di Nagari Situjuah Gadang berhasil mengantarkannya menjadi pengelola klinik keuangan terbaik di Kabupaten Lima Puluh kota tahun 2018. Penelitian ini bertujuan untuk menjelaskan dan menganalisis bentuk partisipasi masyarakat dalam pengelolaan dana desa, dengan menggunakan metode kualitatif, studi kasus instrumental serta menggunakan konsep pembangunan partisipatif dari Mansour Fakih dan empat dimensi partisipasi dari Rusidi. Peneliti berasumsi bahwa partisipasi di Nagari Situjuah Gadang merupakan bentuk partisipasi dalam rekayasa sosial, pasalnya peneliti menemukan bahwa partisipasi yang dilakukan oleh masyarakat dalam pengelolaan dana desa di Nagari Situjuah Gadang Kecamatan Situjuah Limo Nagari Kabupaten Limapuluh Kota masih
\end{abstract}

\footnotetext{
1 Universitas Andalas, Padang, Indonesia.

2 Universitas Andalas, Padang, Indonesia.

3 Universitas Andalas, Padang, Indonesia.
} 
terbatas dalam musyawarah pra perencanaan di tingkat jorong, dengan bentuk partisipasi masyarakat dalam pelaksanaan pembangunan yang dominan, yaitu dalam hal sumbangan tenaga.

Kata kunci: Dimensi Partisipasi; Partisipasi; Tim 5

\section{PENDAHULUAN}

Pengelolaan dana desa perlu mengedepankan partisipasi masyarakat demi meningkatkan kontrol publik atas penggunaan anggaran. Proses perencanaan dan pengelolaan dana desa dimulai dari adanya penyusunan RPJM Desa dengan melibatkan masyarakat desa, sehingga tersaring aspirasi serta gagasan dari masyarakat (Humas DJPK, 2017). Pada dasarnya, partisipasi mengacu kepada adanya keikutsertaan masyarakat, baik itu berupa dukungan, kritikan yang konstruktif, maupun gagasan dalam ekonomi, politik, budaya, dan infrastruktur masyarakat (Mansour Fakih, 2001). Dalam sistem pemerintahan yang bersifat topdown, partisipasi masyarakat dalam sistem yang dibuat dan diimplementasikan tidak begitu dipermasalahkan. Namun, berbeda halnya dengan sistem pemerintahan yang bersifat bottom-up (Kuncoro, 2018: 36). Tinggi rendahnya partisipasi masyarakat dapat dijadikan sebagai tolok ukur keberhasilan suatu kebijakan (Ritantri, 2015). 
Nagari Situjuah berdasarkan berita yang dikeluarkan oleh jurnalsumbar.com pada 31 Januari 2019 menjadi salah satu nagari yang memiliki klinik keuangan pengelolaan dana desa terbaik di Kabupaten Lima Puluh Kota. Hal ini dituturkan oleh Widya Putra, selaku Sekretaris Daerah Kabupaten Lima Puluh Kota didampingi Kepala Badan Keuangan Irwandi, Asisten II Fitma Indrayani, dan Kepala Bidang Data Evaluasi Dandipbang Syofian Hendri kepada media Jurnal Sumbar (jurnalsumbar, 2019).

Hal ini kemudian juga turut dijelaskan oleh Widya Putra kepada dekade.pos bahwasanya salah satu hal yang paling menonjol dari pengelolaan dana desa/dana nagari di Kabupaten Lima Puluh Kota adalah adanya Pelimpahan Kewenangan Pembinaan Keuangan dari Bupati ke Camat, dengan adanya Klinik Keuangan di setiap kecamatan dengan staf yang ditunjuk langsung oleh camat setempat dan diatur oleh Peraturan Bupati No. 13 Tahun 2018 tentang Pelimpahan Kewenangan Evaluasi APBNagari kepada camat sehingga dapat mempercepat upaya pengelolaan dana desa di Klinik Keuangan di Kecamatan Situjuah Limo Nagari, dimana klinik inilah yang melaksanakan pengawasan terhadap nagari yang mengelola dana desa. Melalui klinik keuangan ini tambah Widya, dilakukan pembinaan 
kepada BUMNag, semua hal yang berkaitan tentang keuangan nagari di sanalah kerja klinik keuangan ini, fungsinya untuk mempermudah akses ke pemerintah daerah melalui camat (dekadepos, 2019).

Klinik keuangan yang menjadi pelopor nagari sebagai pengelola dana desa ini pertama kali diluncurkan di Kecamatan Harau Kabupaten Lima Puluh Kota oleh Bupati Irfendi Arbi (portalberitaeditor, 2017). Sebagai tempat untuk berkonsultasi dan berkoordinasi oleh aparatur nagari mengenai pengelolaan keuangan nagari, tujuannya supaya tidak terjadi masalah hukum maupun administratif, dan pengelolaan dana desa tersebut berjalan lancar dan pembangunan serta pemberdayaan masyarakat tepat sasaran.

Keberadaan klinik keuangan sebagai bentuk kontrol pemerintah daerah atas penggunaan dana desa untuk memastikan penggunaan anggaran sesuai dengan tujuan pembangunan. Proses pemantauan tersebut sebagaimana tertuang dalam Peraturan Bupati Kabupaten Lima Puluh Kota No. 13 Tahun 2018 tentang Pelimpahan Kewenangan Evaluasi APBNagari kepada camat dan juga selanjutnya adanya penerbitan Surat Keputusan (SK) Camat Tahun 2018 mengenai standar pembinaan dan pengawasan camat mengenai penyusunan program pembangunan, yangmana dalam 
SK tersebut menjelaskan mengenai standar pembinaan dan pengawasan camat dalam memfasilitasi penyusunan perencanaan dan pelaksanaan pembangunan di Kecamatan Situjuah Limo Nagari Kabupaten Lima Puluh Kota, di antaranya menjelaskan mengenai perencanaan pembangunan nagari yang dimulai dari penyusunan RPJM nagari, RKP desa, serta tahap pembangunan desa dari tahap persiapan pembangunan hingga tahap pelaksanaan kegiatan.

Adanya pelimpahan kewenangan dari bupati ke camat setempat dalam melakukan pembinaan dan pengawasan terhadap pembangunan dan pengelolaan dana desa melalui klinik keuangan merupakan akses langsung bagi camat untuk dapat memantau setiap tahapan dalam pembangunan nagari dan pengelolaan dana desa sejauhmana melibatkan masyarakat secara partisipatif.

Berdasarkan realita di lapangan, ada keunikan dalam melihat partisipasi masyarakat di Nagari Situjuah Gadang tersebut. Dengan kondisi keterbatasan mereka dari segi tingkat pendidikan dan pengetahuan tentang pengelolaan dana desa, tetapi mereka berhasil menempatkan nagari ini sebagai pengelola keuangan terbaik di Kabupaten Limapuluh Kota. Hal ini perlu dipelajari lebih mendalam, apalagi belum ada kajian 
sejenis yang melihat dimensi ini dalam pengelolaan dana desa.

Berdasarkan fenomena tersebut, agar penelitian ini menjadi terarah dan ruang lingkup tidak terlalu luas, maka peneliti membatasi dengan kajian penelitian untuk melihat, bagaimana model partisipasi masyarakat dalam pengelolaan dana desa? Untuk menjawab pertanyaan penelitian tersebut, penulis memilih kasus pengelolaan dana desa di Nagari Situjuah Gadang Kecamatan Situjuah Limo Nagari di Kabupaten Limapuluh Kota yang menggunakan mekanisme klinik keuangan.

\section{KERANGKA TEORI}

Artikel ini lebih jauh menjelaskan bahwa partisipasi yang ada dalam Nagari Situjuah Gadang merupakan suatu bentuk partisipasi yang ada dalam rekayasa sosial, dengan tidak menempatkan masyarakat sebagai subjek dalam pembangunan. Hal ini dapat dipahami bahwa partisipasi yang dimiliki oleh masyarakat di Nagari Situjuah Gadang pada dasarnya baru sebatas dalam musyawarah pra perencanaan, belum menyentuh dan melibatkan masyarakat secara nyata dalam setiap aspek pengelolaan dana desa-dengan kata lain, proses 
partisipasi masyarakat dalam pengelolaan dana desa pada dasarnya masih dimobilisasi oleh pemerintah.

Mansour Fakih dalam bukunya Sesat Pikir Teori Pembangunan dan Globalisasi memaparkan bahwa dalam pembangunan yang partisipatif, sudah seharusnya masyarakat dijadikan sebagai basis dalam pembangunan dengan menempatkannya sebagai subjek dalam pembangunan itu sendiri, bukan hanya sebagai objek semata. Penempatan masyarakat sebagai subjek dalam pembangunan tersebut memiliki penjelasan yang implisit, yaitu masyarakat harus dilibatkan dalam setiap aspek pembangunan dan pengelolaan dana desa, keterlibatan masyarakat secara nyata dalam pembangunan ini juga akan membangun pengetahuan dan kecerdasan masyarakat dalam pengelolaan desa.

Lebih lanjut, analisis partisipasi yang digunakan dalam penelitian ini menggunakan konsep pembangunan partisipatif yang dijelaskan oleh Mansour Fakih (Mansour Fakih, 2001). Konsep pembangunan partisipatif tersebut yakni konsep yang dapat dipahami sebagai proses bagaimana suatu masyarakat berubah serta dinamika dan proses sekitar perubahan tersebut, dari yang semula berdasarkan regulasi sosial yang menempatkan masyarakat sebagai objek pembangunan 
menuju emansipatori sosial yang menempatkan masyarakat sebagai subjek dari pembangunan.

Kemudian, Rusidi menyebutkan ada empat dimensi dalam berpartisipasi, yang terdiri dari (1) sumbangan pemikiran (ide atau gagasan), (2) sumbangan materi (dana, barang dan alat), (3) sumbangan tenaga (bekerja), dan (4) memanfaatkan dan melaksanakan pelayanan pembangunan (Solekhan, 2014: 152). Hal ini selaras dengan sumberdaya manusia yang dimiliki oleh Nagari Situjuah Gadang. Kepadatan penduduk Nagari Situjuah Gadang di rentang usia produktif serta keberagaman pendidikan akan memengaruhi persepsi serta kemampuan masyarakat dalam mengakumulasikan ide dalam melakukan musyawarah dan berpartisipasi dalam melaksanakan pembangunan nantinya.

Konsep pembangunan partisipatif Mansour Fakih dalam halnya akan mengelaborasi lebih jauh proses partisipasi masyarakat dalam pembangunan yang dilakukan di Nagari Situjuah Gadang dalam tahapantahapan pengelolaan dan pelaksanaannya yang menggunakan mekanisme klinik keuangan. 


\section{KASUS NAGARI SITUJUAH GADANG}

Nagari Situjuah Gadang merupakan salah satu dari lima nagari yang terletak di Kecamatan Situjuah limo Nagari, Kabupaten Lima Puluh Kota. Nagari Situjuah Gadang memiliki jumlah penduduk dengan kepadatan yang cukup tinggi, yaitu sejumlah 5.908 jiwa dan luas wilayah $16.9 \mathrm{Km}^{2}$. Dari total jumlah penduduk keseluruhan tersebut terdapat 3.884 jiwa yang berada dalam rentang usia 15-64 tahun. Dalam konteks ini, hal tersebut dapat dipahami sebagai masyarakat yang telah memiliki hak serta kemampuan untuk ikut serta secara aktif untuk berpartisipasi dalam pengelolaan dana desa. Berikut disajikan data tabel 1.1 penduduk berdasarkan kelompok umur di Nagari Situjuah Gadang. 


\section{Tabel 1.1. Jumlah Penduduk Menurut Kelompok Umur Per-Jorong}

\begin{tabular}{cccccccc}
\hline $\begin{array}{c}\text { Kelompok } \\
\text { Umur }\end{array}$ & Kociak & $\begin{array}{c}\text { Padang } \\
\text { Jariang }\end{array}$ & $\begin{array}{c}\text { Padang } \\
\text { Kuniang }\end{array}$ & $\begin{array}{c}\text { Situjuah } \\
\text { Gadang }\end{array}$ & $\begin{array}{c}\text { Tanjuang } \\
\text { Bungo }\end{array}$ & $\begin{array}{c}\text { Tanjuang } \\
\text { Simantuang }\end{array}$ & Jumlah \\
\hline 00-04 & 61 & 54 & 80 & 82 & 58 & 40 & 375 \\
05-09 & 86 & 71 & 129 & 111 & 67 & 70 & 534 \\
$10-14$ & 102 & 81 & 115 & 118 & 79 & 72 & 567 \\
$15-19$ & 81 & 91 & 125 & 102 & 67 & 55 & 521 \\
$20-24$ & 101 & 102 & 109 & 105 & 61 & 57 & 535 \\
$25-29$ & 65 & 59 & 91 & 65 & 53 & 38 & 371 \\
$30-34$ & 67 & 40 & 69 & 70 & 50 & 48 & 344 \\
$35-39$ & 74 & 62 & 77 & 89 & 54 & 62 & 418 \\
$40-44$ & 61 & 69 & 87 & 96 & 59 & 52 & 424 \\
$45-49$ & 65 & 57 & 78 & 76 & 32 & 38 & 346 \\
$50-54$ & 46 & 61 & 82 & 78 & 38 & 42 & 347 \\
$55-59$ & 42 & 44 & 60 & 51 & 42 & 39 & 278 \\
$60-64$ & 35 & 44 & 61 & 59 & 30 & 31 & 260 \\
$65-69$ & 33 & 36 & 51 & 39 & 31 & 28 & 218 \\
$70-74$ & 22 & 17 & 33 & 28 & 15 & 17 & 132 \\
75 Ke atas & 28 & 28 & 62 & 67 & 19 & 34 & 238 \\
Total & & & & & & & $\mathbf{5 9 0 8}$ \\
\hline
\end{tabular}

Sumber: Dikelola oleh Peneliti dari Data Jumlah Penduduk Semester 1 Tahun 2019 Kantor Wali Nagari Situjuah Gadang Tahun 2021

Berdasarkan penggolongan usia dari tabel 1.1. di atas dan menurut data BPS, seseorang dapat dikatakan dalam usia produktif yaitu berada dalam rentang usia 15-64 tahun. Dalam rentang usia tersebut dengan kondisi fisik dan psikis yang dimilikinya, maka memungkinkan seseorang dapat berpartisipasi secara aktif. Sebagaimana yang dijelaskan oleh Kusrini et.al. (2013) bahwasanya 
usia produktif membuat masyarakat dapat bekerja secara optimal. Rentang usia produktif yang dimiliki oleh masyarakat di Nagari Situjuah Gadang tersebut seharusnya memungkinkan untuk ikut serta secara aktif dalam setiap tahapan pengelolaan dana desa.

Akan tetapi, dari jumlah penduduk tersebut sebagian besar penduduk di Nagari Situjuah Gadang tidak tamat sekolah dasar sejumlah 2.159 jiwa, tamat SD/Sederajat 787 jiwa, Menengah Pertama 652 jiwa, dan yang menamatkan Sekolah Menengah Atas hanya sejumlah 907 jiwa, serta yang menempuh Pendidikan Tinggi hingga Diploma IV/Strata I hanya berjumlah 177 jiwa, dan yang berpendidikan hingga Strata II hanya 3 jiwa hingga tahun 2018. Sebagaimana dijelaskan oleh Rusidi (Solekhan, 2014) dalam melaksanakan tahapan musyawarah pada pengelolaan dana desa masyarakat akan berpartisipasi dengan memberikan sumbangan pemikiran, yang dapat dipengaruhi oleh pendidikan yang dimiliki oleh masyarakat. Berikut digambarkan tingkat pendidikan yang dimiliki oleh masyarakat di Nagari Situjuah Gadang. ${ }^{4}$

4 Sumber data primer dari Kantor Wali Nagari Situjuah Gadang yang dikelola oleh peneliti Pada tanggal 10 Januari 2020. 
Tabel 1.2. Jumlah Penduduk Menurut Pendidikan

\begin{tabular}{llllll}
\hline Jorong & $\begin{array}{l}\text { Belum } \\
\text { Tamat SD/ } \\
\text { Sederajat }\end{array}$ & $\begin{array}{l}\text { Tamat SD/ } \\
\text { Sederajat }\end{array}$ & $\begin{array}{l}\text { SLTP/ } \\
\text { Sederajat }\end{array}$ & $\begin{array}{l}\text { SLTA/ } \\
\text { Sederajat }\end{array}$ & $\begin{array}{l}\text { Akademi/ } \\
\text { Perguruan } \\
\text { Tinggi }\end{array}$ \\
\hline Kociak & 397 & 11 & 100 & 116 & 22 \\
Padang Jariang & 313 & 148 & 120 & 155 & 34 \\
Padang kuniang & 459 & 126 & 154 & 232 & 81 \\
Situjuah Gadang & 403 & 156 & 119 & 205 & 112 \\
Tanjuang Bungo & 296 & 153 & 88 & 103 & 23 \\
Tanjuang & 291 & 91 & 71 & 96 & 26 \\
Simantuang & & & & & \\
\hline
\end{tabular}

Sumber: Dikelola oleh Peneliti dari Jumlah Penduduk Semester 1 Tahun 2019 Kantor Wali Nagari Situjuah Gadang Tahun 2021

Berdasarkan tabel 1.2. tersebut, dapat dipahami bahwa perbandingan masyarakat yang putus sekolah dengan masyarakat yang menempuh pendidikan didominasi pada setiap jorong oleh angka masyarakat yang putus sekolah. Hal inilah yang dapat memengaruhi keikutsertaan dan kemampuan masyarakat dalam memberikan sumbangan ide/pemikiran dalam musyawarah desa. Merujuk dari tabel 1.2. tersebut dan data jumlah penduduk yang memiliki rentang usia produktif untuk ikut serta dalam pengelolaan dana desa di Nagari Situjuah Gadang, maka dapat disajikan dalam tabel 1.3. berikut persentase perbandingan antara masyarakat yang memiliki usia produktif 
partisipasi dengan tingkat pendidikan yang dimiliki oleh masyarakat.

\section{Tabel 1.3. Jumlah dan Persentase Penduduk menurut Pendidikan dan Rentang Usia Produktif}

\begin{tabular}{lllll}
\hline Masyarakat & Jumlah & \multicolumn{3}{l}{ Total } \\
& $N$ & $\%$ & $N$ & $\%$ \\
Putus sekolah & 2159 & 36 & 5908 & 100 \\
Tamat SD & 787 & 13.3 & 5908 & 100 \\
SMP & 652 & 11 & 5908 & 100 \\
SMA & 907 & 15.35 & 5908 & 100 \\
Usia 16-64 Tahun & 3844 & 65 & 5908 & 100 \\
\hline
\end{tabular}

Sumber: Dikelola oleh Peneliti dari Jumlah Penduduk Semester 1 Tahun 2019 Kantor Wali Nagari Situjuah Gadang Tahun 2021

Berdasarkan persentase dalam tabel di atas, dapat dilihat bahwa penduduk dengan rentang usia 16-64 tahun memiliki persentase yang tinggi untuk ikut secara aktif dalam pembangunan dan pengelolaan dana desa di Nagari Situjuah Gadang. Namun, persentase pendidikan yang dimiliki oleh masyarakat masih terbilang kecil. Kemudian, Nagari Situjuah Gadang dinyatakan menjadi klinik keuangan terbaik yang diiringi dengan partisipasi masyarakatnya yang cukup tinggi. Salah satunya, dibuktikan dengan hadirnya masyarakat dalam musyawarah nagari untuk merumuskan Rancangan Kerja Pemerintahan (RKP) nagari. Kehadiran masyarakat ini 
tampak dari absensi rapat yang dihadiri oleh sejumlah perwakilan dari unsur masyarakat, seperti terlihat di tabel 1.4. dan tabel 1.5. berikut.

\section{Tabel 1.4. Daftar Kehadiran Unsur Masyarakat dalam Musyawarah Nagari Perencanaan RKP Nagari}

\begin{tabular}{lll}
\hline No & Nama Unsur Masyarakat & Jumlah \\
\hline 1. & Tim Rancangan Kerja Pemerintahan (RKP) & 5 \\
2. & Tenaga Kesehatan & 4 \\
3. & Tenaga Pendidik & 7 \\
4. & Tim MusyawarahNagari (MUNA) & 6 \\
5. & Tim Pembina KesejahteraKeluarga (PKK) & 3 \\
6. & KepalaJorong & 3 \\
7. & Tim 5 & Tim Kader KesehatandanKeluargaBerencana (KB) \\
8. & Bhayangkara Pembina Keamanan dan Ketertiban Masyarakat & 3 \\
9. & (BABINKAMTIBNAS) serta Linmas & 5 \\
& Unsur Pemerintahan Nagari & 7 \\
10. & Utusan Camat & 3 \\
12. & Perwakilan setiap jorong & 3 \\
& Total & 19 \\
\hline
\end{tabular}

Sumber: Data Primer (Dikelola Peneliti dari Daftar Hadir Musyawarah Nagari Perencanaan AKP Nagari Situjuah Gadang) Tahun 2021 


\section{Tabel 1.5. Jumlah Penduduk Produktif dengan Persentase Partisipasi Pengelolaan Dana Desa}

\begin{tabular}{llclc}
\hline \multicolumn{1}{c}{ Masyarakat } & \multicolumn{3}{c}{ Partisipasi Rapat RKP } & Total \\
& $\mathrm{N}$ & $\%$ & $\mathrm{~N}$ & $\%$ \\
Nagari & 1.85 & 3.844 & 100 \\
Tidak ikut & 72 & 97.11 & 3.844 & 100 \\
musyawarah & 3.772 & & & \\
\hline
\end{tabular}

Sumber: Data Primer (Dikelola Peneliti dari Daftar Hadir Musyawarah Nagari Perencanaan AKP Nagari Situjuah Gadang) Tahun 2021

Berdasarkan tabel 1.4. dan 1.5. tersebut, jika dilihat perbandingan antara persentase kehadiran masyarakat dalam musyawarah dengan jumlah masyarakat yang diwakili memiliki jarak yang sangat jauh berbeda. Meskipun secara administratif masyarakat telah memiliki wakil dari setiap unsur kelompok atau kategori yang ada dalam masyarakat untuk ikut dalam mewakili di musyawarah tingkat nagari, hal ini belum tentu dapat mewakili setiap aspirasi masyarakat.

Nagari Situjuah Gadang yang merupakan salah satu pemilik klinik keuangan terbaik di Kabupaten Lima puluh Kota pun harus didukung dengan pengelolaan dana desa yang baik, yang melibatkan masyarakat dalam setiap tahapannya. Sebagaimana dijelaskan oleh Tisya Alya Arifiany \& Sofyan Sjaf (2018) dalam penelitian 
yang berjudul Analisis Respon Masyarakat terhadap Pengelolaan Dana Desa untuk Pembangunan Pedesaan (Desa Pesantren, Kecamatan Ulujami, Kabupaten Pemalang, bahwasanya pengelolaan dana desa yang baik akan meningkatkan partisipasi masyarakat. Partisipasi masyarakat ini selaras dengan pendidikan dan ekonomi yang dimiliki oleh masyarakat tersebut. Sebab, perbedaan mayoritas masyarakat yang memiliki pendidikan yang lebih tinggi memiliki sikap yang lebih responsif dalam pengelolaan dana desa, yaitu memiliki kesadaran untuk ikut serta dalam pengelolaan dana desa.

Hal serupa seharusnya ditemukan dalam pengelolaan dana desa di Nagari Situjuah Gadang sehingga dapat mendukung kondisi yang mengantarkannya menjadi salah satu daerah dengan klinik keuangan terbaik. Namun dalam temuan lapangan yang peneliti peroleh, pengelolaan dana desa yang baik dengan partisipasi yang tinggi di Nagari Situjuah Gadang tidak didukung dengan tingkat pendidikan dan sosial ekonomi yang dimiliki oleh masyarakat. Tidak jarang ditemui dalam Nagari Situjuah Gadang tersebut masih banyak masyarakat yang memiliki keterbatasan pengetahuan dalam pengelolaan dana desa. Padahal, memiliki partisipasi yang tinggi dalam pengelolaannya. 
Keterbatasan pengetahuan yang dimiliki oleh masyarakat ini tidak lain disebabkan karena rendahnya tingkat pendidikan yang dimiliki oleh masyarakat di Nagari Situjuah Gadang tersebut, serta kurangnya komunikasi perangkat nagari dalam menyosialisasikan program dana desa yang diikuti dengan rendahnya tingkat pendidikan masyarakat yang menyebabkan kurangnya pemahaman masyarakat terkait dana desa. Hal ini sejalan tinjauan penelitian terdahulu Dewi Listyawati, Sarmiati, dan Asmawi pada tahun 2019 dengan judul Komunikasi Perangkat Nagari dan Partisipasi Masyarakat dalam Pengelolaan Dana Desa, yang menerangkan bahwa kurangnya komunikasi perangkat nagari dalam menyosialisasikan program dana desa yang diikuti dengan rendahnya tingkat pendidikan masyarakat yang menyebabkan kurangnya pemahaman masyarakat terkait dana desa (Listyawati et.al., 2019).

\section{PEMBAHASAN}

Program pembangunan partisipatif yang bertautan dengan masyarakat merupakan suatu bentuk bottomupplanning. Peran masyarakat dalam pembangunan bukanlah lagi sebagai objek dari suatu pembangunan, melainkan subjek dari pembangunan itu sendiri. 
pembangunan yang partisipatif ialah pembangunan yang menyejajarkan kata pembangunan dengan perubahan sosial dan dinamika yang ada dalam masyarakat itu sendiri, sebagaimana yang disampaikan oleh Mansour Fakih.

Dengan demikian, dalam konsep pembangunan partisipatif masyarakat ditempatkan sebagai pelaku utama pembangunan dan pemerintah, tidak lagi sebagai provider, tetapi lebih bertindak sebagai intermediasi dan katalisator segenap perencanaan pembangunan. Artinya, pemerintah seharusnya memberikan kepercayaan dan kesempatan yang lebih banyak kepada masyarakat, di dalam menumbuh-kembangkan segala potensi yang dimilikinya bersama dengan lingkungannya sehingga dapat menjadi suatu bagian integral dan menjadi subjek yang dominan dalam menentukan keberhasilan dalam suatu daerah (Muthalib, Abdul, 2016: 99). 


\section{ANALISIS BENTUK-BENTUK PARTISIPASI \\ MASYARAKAT DALAM PENGELOLAAN \\ DANA DESA DI NAGARI SITUJUAH GADANG \\ KECAMATAN SITUJUAH LIMO NAGARI \\ KABUPATEN LIMA PULUH KOTA}

Berjalannya program dana desa di Nagari Situjuah Gadang Kecamatan Situjuah Limo Nagari Kabupaten Lima Puluh Kota membuahkan hasil yang menarik. Pasalnya, program dana desa yang dijalankan di Nagari Situjuah Gadang meningkatkan prestasi dari nagari tersebut menjadi pengelola klinik keuangan terbaik di Kabupaten Limapuluh Kota. Peningkatan ini terjadi dalam bidang pengelolaan dana desa dengan melibatkan masyarakat sebagai bentuk partisipasi dalam pengelolaan dana desa yang dikelola oleh Pemerintah Nagari Situjuah Gadang. Dalam hal ini, bentuk-bentuk partisipasi yang dilakukan oleh masyarakat Nagari Situjuah Gadang dalam pengelolaan dana desa meliputi beberapa tahapan dapat dilihat dalam Tabel 1.6. di bawah ini: 


\section{Tabel 1.6. Tahapan Partisipasi Masyarakat}

\begin{tabular}{ll}
\hline Tahapan & Kegiatan \\
\hline Pra perencanaan & Menjaring aspirasi \\
& Melakukan evaluasi pembangunan tahun sebelumnya \\
& Membentuk tim 5 \\
Perencanaan (Musyawarah & Tim 5 mewakili jorong masing-masing \\
Gabungan di Nagari) & Menentukan prioritas nagari \\
Pelaksanaan & Pelaksanaan pembangunan prioritas \\
& Tahapan pertama: penilaian dan pemeriksaan \\
Evaluasi & terhadap 40\% \\
& Tahap kedua: penilaian dan pemeriksaan \\
& terhadap 80\% \\
& Tahap ketiga: penilaian dan pemeriksaan \\
& terhadap 100\% \\
\hline
\end{tabular}

Sumber: Data Primer Dikelola oleh Peneliti Berdasarkan Data

Penelitian Lapangan di Nagari Situjuah Gadang Tahun 2021

Berdasarkan tabel 1.6. tersebut, keterlibatan masyarakat pertama kali dan secara langsung terjadi dalam musyawarah pra perencanaan di jorong masingmasing. Hal tersebut juga diungkapkan oleh Syofiarledi selaku Wali Nagari Situjuah Gadang bahwa keterlibatan masyarakatdalam musyawarah dasardiawal perencanaan ini merupakan bentuk partisipasi masyarakat paling pertama (Wawancara 15 Mei 2020 pukul 09.30 WIB). Dalam musyawarah tersebut juga dibentuk Tim 5 untuk membawa aspirasi ke tingkat nagari. Hal ini ditegaskan kembali oleh Arwinsyaf selaku Kepala Jorong Tanjuang 
Simantuang (Wawancara 18 Mei 2020 pukul 19.00 WIB). Tim 5 selain untuk membawa aspirasi juga secara langsung diangkat oleh Wali Nagari untuk menjadi tim pelaksana kegiatan pembangunan apabila aspirasi dari jorong yang diwakilinya mendapat bantuan dan dipilih sebagai prioritas nagari pada tahun anggaran tersebut. Berikut juga dalam Tim 5 ini memiliki keterwakilan $30 \%$ dari perempuan sehingga setiap pembentukan Tim 5 pasti melibatkan perempuan dalam pengambilan kebijakannya, terang Kepala Jorong Situjuah Gadang (Wawancara 4 Juni 2020 pukul 16.30 WIB).

Musyawarah tingkat nagari ini merupakan musyawarah kedua atau disebut juga musyawarah gabungan pada tahapan partisipasi kedua. Selain untuk menyaring aspirasi yang dibawa oleh Tim 5 ke musyawarah tingkat nagari, akan dilakukan penetapan prioritas pembangunan dari hasil musyawarah tersebut. Pembangunan yang berada dalam skala prioritas akan langsung dilakukannya kesepakatan mengenai tenaga kerja, besaran upah, sistem pengerjaan (borongan/ harian), dan juga swadaya masyarakat yang akan digunakan dalam melakukan pembangunan yang telah disepakati sebelumnya.

Ketiga, yaitu diadakannya tahap pelaksanaan kegiatan. Dalam tahap pelaksanaan kegiatan ini, 
masyarakat dapat berpartisipasi baik dalam hal tenaga maupun swadaya dan bergotong-royong. Dalam hal partisipasi masyarakat dalam penggunaan tenaga, pada pelaksanaan kegiatan ini terdapat dua bagian. Pertama, yaitu dengan cara menjadi pekerja dalam pembangunan yang dilakukan, kemudian menerima upah dari pelaksanaan pekerjaan tersebut. Kedua, dalam Jorong Kociak sebagaimana yang dituturkan oleh Doni Sartika selaku Kepala Jorong (Wawancara 18 mei 2020 Pukul 10.00 WIB), adanya sistem yang berbeda dalam tahapan partisipasi masyarakat dalam tenaga di Jorong Kociak dengan jorong lainnya, masyarakat yang bekerja sebagai buruh dalam pelaksanaan kegiatan tersebut akan menyumbangkan upah satu hari kerja dalam rentang waktu satu minggu kepada nagari sebagai bentuk partisipasi dan bantuan dari pekerja untuk membantu jalannya pembangunan nagari (Wawancara dengan Doni Sartika 18 Mei 2020).

Lebih lanjut, dalam hal tahapan evaluasi dan monitoring pemeriksaan pelaksanaan kegiatan infrastruktur yang dilakukan berdasarkan Peraturan Bupati No. 25 Tahun 2018 tentang Petunjuk Teknis Penggunaan Dana Desa pasal 37, yaitu pemeriksaan 40\%, 80\%, dan 100\%. Apabila didapati dalam kunjungan lapangan tidak mencapai persentase pada tahapan 
kunjungan, maka akan diadakan evaluasi kendala pelaksanaan kegiatan dan kegiatan harus dituntaskan terlebih dahulu sebelum dicairkan dana selanjutnya. Sejalan dengan apa yang dituturkan oleh Sekretaris Nagari Hendra Doni bahwasanya pencairan dana bertahap ini bertujuan agar realisasi dari setiap dana yang telah dicairkan memperlihatkan hasil yang nyata (Wawancara18 Mei 2020 pukul 08.30 WIB).

"Kalaulah dapek hasil pemantauan 40\% beko dibaliak an nyoka TPK, TPK beko maundang masyarakat kito baliak, namo e adalah laporan pertanggungjawaban 40\%. Di situ disampaikan baliak rencana awal dulu, bara nan lah dikarajoan, kendala apo sajo nan ditemui, beko di akhir musyawarah salah satu yang diputuskan adalah ditarimo atau indak dek masyarakat kegiatan yang $40 \%$ berjalan ko (Kalau sudah didapatkan hasil pemantauan 40\% TPK akan mengundang masyarakat untuk bermusyawarah kembali, yang dinamakan musyawarah pertanggungjawaban 40\%. Yang mana dalam musyawarah tersebut akan disampaikan kembali rancangan awal, hasil yang telah dikerjakan, dan kendala selama pengerjaan. Salah satu kesepakatan akhir nantinya akan meminta pendapat masyarakat mengenai kegiatan 40\% apakah layak dilanjutkan)."

Begitu pula dalam hal pencairan dana, ini tidak akan diberikan langsung kepada kepala jorong. Dana ini akan tetap dikelola oleh bagian keuangan nagari dengan terus berkoordinasi dengan sekretaris nagari 
dan wali nagari. Segala urusan mengenai pendanaan ini akan selalu dikoordinasikan dengan nagari, pembelian dan pembayaran bahan juga dilakukan langsung oleh Pemerintah Nagari Situjuah Gadang, yakni mencakup fungsi dan tugas dari kepala urusan keuangan sebagaimana yang dijelaskan oleh Deni Zulya selaku kaurkeungan Nagari Situjuah Gadang (Wawancara 18 Mei 2020 pukul 11.41 WIB).

Pembangunan ini dapat diambil contoh prioritas nagari pada tahun 2018 ketika dinyatakannya Nagari Situjuah Gadang sebagai pengelola dana desa terbaik di Kabupaten Limapuluh Kota, yaitu adanya pembangunan fisik seperti dalam tabel berikut:

\section{Tabel 1.7 Kegiatan Pembangunan Tahun 2018 Nagari Situjuah Gadang}

\begin{tabular}{lll}
\hline No & Kegiatan & Lokasi \\
\hline 1. & Pembangunan Pembukaan Jalan nagari SD 07-Tanjuang & Jorong Padang Jariang \\
& Bungo & \\
2. & Pembangunan Pembukaan Jalan Nagari Mesjid-Tanah & Jorong Tanjuang Simantuang \\
& Sirah & \\
3. & Pembangunan Jalan Nagari Sipisang-Ikua Kandang & Jorong Padang Kuniang \\
4. & Rehab Lapangan Bola Kaki Limo Suku Situjuah Gadang & Jorong Situjuah Gadang \\
5. & Pembangunan Rumah Layak Huni & Nagari Situjuah Gadang \\
6. & Pembangunan Kantor Wali Nagari Situjuah Gadang & Kantor Wali Nagari Situjuah \\
& & Gadang \\
\hline
\end{tabular}

Sumber: Dikelola oleh Peneliti dari Arsip Dokumen

Pemerintahan Nagari Situjuah Gadang Tahun 2021 
Selanjutnya, berdasarkan hasil temuan lapangan dan analisis dalam hal bentuk-bentuk partisipasi yang dilakukan oleh masyarakat di Nagari Situjuah Gadang dalam halnya pengelolaan dana desa telah dapat menjawab tujuan penelitian yang bermaksud untuk menjelaskan dan menganalisis bentuk-bentuk partisipasi masyarakat dalam pengelolaan dana desa di Nagari Situjuah Gadang. Berdasarkan penelitian tersebut, dapat peneliti simpulkan bahwasanya konsep pembangunan partisipatif sebagaimana yang dikemukakan oleh Mansour Fakih bahwa masyarakat dalam pembangunan di tempatkan sebagai subjek, bukanlah objek dalam sebuah pembangunan. Hal ini tidak begitu relevan dengan apa yang peneliti temui dalam proses partisipasi yang dilakukan di Nagari Situjuah Gadang. Nagari Situjuah Gadang secara konseptual memang telah menerapkan partisipasi masyarakat, tetapi secara aplikatifnya konsep partisipasi ini tidak nyata adanya. Hal ini terbukti dengan partisipasi masyarakat dalam pengelolaan dana desa yang paling dominan hanya terdapat pada saat perumusan awal di jorong masingmasing.

Selanjutnya, dalam pengelolaan dana desa di Nagari Situjuah Gadang terdapat partisipasi masyarakat yang sejalan dengan subteori dari Rusidi, yang peneliti 
gunakan untuk melihat bentuk-bentuk partisipasi masyarakat. Pertama, bentuk partisipasi masyarakat dalam bentuk sumbangan tenaga dalam pengerjaan pembangunan maupun pemberdayaan masyarakat. Kedua, sumbangan ide/gagasan dalam hal perencanaan untuk penggunaan dana desa kedepannya. Ketiga, terdapatnya sumbangan materil dari masyarakat dalam bentuk bantuan bahan-bahan, seperti batu, pasir, kerikil dalam pembangunan, dan juga adanya bantuan dari masyarakat berupa pembebasan lahan tanpa ganti rugi. Berdasarkan beberapa hasil temuan, peneliti juga membandingkan dengan temuan sebelumnya. Temuan peneliti mengungkapkan kebaruan bahwasanya dalam pendidikan, ekonomi, dan pekerjaan masyarakat tidak berpengaruh signifikan atas partisipasi yang dilakukan oleh masyarakat.

\section{ANALISIS DAN IDENTIFIKASI DIMENSI YANG DOMINAN DALAM PROSES PARTISIPASI MASYARAKAT DALAM PENGELOLAAN DANA DESA DI NAGARI SITUJUAH GADANG KECAMATAN SITUJUAH LIMO NAGARI KABUPATEN LIMA PULUH KOTA}

Partisipasi merupakan hal yang era $\mathrm{t}$ kaitannya dengan pemberdayaan masyarakat. Pemberdayaan 
masyarakat dinilai berhasil atau tidak terlihat dari bagaimana partisipasi masyarakatnya dalam proses pemberdayaan tersebut (Adenansi et.al., 2015: 349). Rusidi menyebutkan ada empat dimensi dalam berpartisipasi, yang terdiri dari (1) sumbangan pemikiran (ide atau gagasan), (2) sumbangan materi (dana, barang, dan alat), (3) sumbangan tenaga (bekerja), dan (4) memanfaatkan dan melaksanakan pelayanan pembangunan (Solekhan, 2014 :152). Hal ini kemudian dipertegas dengan adanya Peraturan Menteri Dalam Negeri No. 20 Tahun 2018 Pasal 12 Tentang Pengelolaan Keuangan Desa bahwasanya sumbangan atau partisipasi masyarakat dalam pengelolaan dana desa itu dapat dilihat dari tiga aspek utama, yaitu adanya swadaya, partisipasi dan gotong-royong.

Dalam aspek pertama, sumbangan pemikiran artinya masyarakat terlibat aktif dalam memberikan saran dan masukan dalam proses perencanaan dan evaluasi pembangunan yang dilakukan dalam musyawarah nagari yang dilakukan sebelum dan setelah pelaksanaan pembangunan. Berdasarkan pembangunan dan pengelolaan dana desa yang dilakukan di Nagari Situjuah Gadang, keikutsertaan masyarakat ini dapat dilihat dalam beberapa indikator, yaitu (1) Keterlibatan masyarakat dalam menyampaikan aspirasi di tingkat 
jorong dalam proses pra perencanaan pembangunan yang dilaksanakan, (2) Keterlibatan masyarakat dalam menetapkan skala prioritas atas rencana pembangunan Nagari Situjuah Gadang, dan (3) Keterlibatan masyarakat dalam mengambil keputusan untuk memperkirakan kebutuhan anggaran pembangunan Nagari Situjuah Gadang.

Keterlibatan masyarakat dalam proses musyawarah pada tingkatan pertama ini memiliki kecenderungan tidak dihadiri oleh seluruh masyarakat, dalam artian masyarakat yang hadir dalam proses perencanaan ini orang yang sama pada tiap tahun perencanaannya. Dengan demikian, kebijakan yang dihasilkan pun tentu dari pemikiran yang sama dan tidak memiliki variasi dan dikhawatirkan tidak mewakili semua aspirasi masyarakat. Hal ini pun dibenarkan oleh Ketua Badan Permusyawaratan Nagari Situjuah Gadang Fetri Arizal ketika ditemui di lapangan (Wawancara 18 Mei 2020 pukul 12.10 WIB).

"Kalau di awak Nagari Situjuah Gadang kan ado beberapa macam musyawarah, ado yang di jorong, ado yang di nagari. Itu menampuang aspirasi dari masyarakat itu melalui musyawarah jorong. Dalam musyawarah ini akan ada perwakilan Bamus yang ada di jorong masing-masing tersebut untuk ikut serta dalam musyawarah tersebut. Kalau menurut yang biaso 
masyarakat lai ado partisipasinyo, sekitar 60\% dari masyarakat, ado yang tokoh masyarakat, ado kelompokkelompok yang ado dalam masyarakat...jadi memang terkadang ado perbedaan pendapat dalam musyawarah, dan iko kadang juo dipengaruhi dek gengsi masyarakat, ado nan maraso labiah dari nan lain. Kadang dalam musyawarah awak ko masyarakat lai datang, cuma masyarakat mandanga sajo, dan yang kamangecek tu urang nyo itu-itu sajo (Kalau di Nagari Situjuah Gadang ini ada beberapa macam musyawarah, ada yang di jorong, ada yang di Nagari. Untuk menampung aspirasi dari masyarakat melalui musyawarah jorong. Dalam musyawarah ini aka nada perwakilan Bamus yang ada di jorong masing-masing tersebut untuk ikut serta dalam musyawarah tersebut. Kalau menurut yang biasanya masyarakat ikut berpartisipasi, sekitar $60 \%$. Ada yang dari tokoh masyarakat, ada yang dari kelompok-kelompok masyarakat, ... jadi terkadang memang ada perbedaan pendapat dalam musyawarah, dan terkadang dipengaruhi oleh gengsi masyarakat, ada yang merasa melebihi yang lainnya. Kadang dalam musyawarah masyarakat kita memang hadir, tetapi sebatas mendengar, dan yang berpendapat tetap orang yang sama)."

Dalam halnya pelaksanaan musyawarah di tingkat jorong, dalam tahapan pra perencanaan ini masyarakat yang hadir sebagaimana dijelaskan sebelumnya memang terkadangbisa mencapai 60\% darimasyarakat. Tetapidari persentase masyarakat yang hadir dalam musyawarah tersebut, tidaklah semua masyarakat mampu untuk 
berbicara dan mengedepankan aspirasinya di depan umum. Mereka cenderung diam dalam musyawarah, tetapi ketika berada dalam perkumpulan yang lebih kecil seperti kebiasaan orang Minang duduk di kadai kopi (warung kopi), mereka menjelaskan secara terangterangan tentang apa yang mereka inginkan. Hal ini juga disebabkan karena rasa malu dan mindernya dengan masyarakat lain yang lebih mampu untuk berbicara dengan bahasa yang lebih tertata di depan umum dan memiliki pengalaman yang lebih. Hal ini pun turut dibenarkan oleh Kepala Jorong Padang Kuniang Ifdal Nasir (Wawancara 18 Mei 2020 pukul 10.30 WIB).

Kedua, yaitu adanya sumbangan materi yang dilakukan oleh masyarakat di Nagari Situjuah Gadang, Terdapatnya pemberian bantuan material atau bahanbahan untuk kegiatan pembangunan yang dilaksanakan, dalam sumbangan materi ini dapat dilihat dalam beberapa indikator, yakni (1) Terdapatnya bantuan dana dalam biaya perawatan hasil pembangunan yang telah ada di Nagari Situjuah Gadang. Bantuan ini biasanya datang dari para perantau Nagari Situjuah Gadang untuk perawatan maupun perbaikan pembangunan, (2) adanya pemberian bantuan berupa bahan bangunan, hibah tanah dari masyarakat, kayu, dan sebagainya yang diperlukan dalam proses pembangunan. 
Selanjutnya, dalam aspek sumbangan tenaga dalam proses pelaksanaan pembangunan masyarakat lebih cenderung untuk bergotong-royong. Hal Ini merupakan aspek yang paling dominan dalam hal partisipasi yang diberikan oleh masyarakat dalam pembangunan, mengingat dalam lingkup Nagari Situjuah Gadang yang didominasi oleh masyarakat petani, memiliki tingkat pendidikan yang cenderung rendah, dan penghasilan yang dimiliki oleh masyarakat rata-rata tidak terlalu tinggi sehingga mengakibatkan masyarakat lebih mengandalkan tenaga untuk berpartisipasi. Berdasarkan hal tersebut, dapat disimpulkan bahwasanya dimensi partisipasi yang dominan dalam pengelolaan dana desa di Nagari Situjuah Gadang ialah dalam hal bantuan keterlibatan masyarakat dari segi sumber tenaga yang digunakan oleh masyarakat.

Hal ini pun dibenarkan oleh Arion selaku Kepala Bidang Pemerintahan Kecamatan Situjuah Limo Nagari yang pernah menjabat sebagai Sekretaris Nagari Situjuah Gadang (Wawancara 19 Mei 2020 pukul 09.00 WIB).

"Tapi, yang ambo lihat, kebanyakan dari masyarakat koyo cuman dalam segi tenaga, baa kok baitu, karna awak kalau sumbangan dari segi dana dan bahan itu lebih banyak berasal dari perantau. Danjuo, dalam masa 
penggalian gagasan itu, masyarakat lebih cenderung untuak duduak maota di lapau atau kadai, dari pada mengeluarkan gagasan di dalam forum musyawarah (Tapi, yang saya lihat, kebanyakan dari masyarakat ini hanya berpartisipasi dalam bentuk tenaga. Kenapa demikian, karena kalau sumbangan dari segi dana dan bahan lebih banyak dari perantau. Danjuga, dalam masa penggalian gagasan masyarakat lebih cenderung untuk duduk dan bertukar pendapat di kedai kopi daripada dalam forum musyawarah)."

Berdasarkan beberapa hasil temuan, peneliti juga membandingkan dengan hasil terdahulu bahwasanya ada disparitas partisipasi Nagari Situjuah Gadang dengan temuan penelitian sebelumnya di daerah lain. Temuan peneliti mengungkapkan kebaruan sebagai pembanding dari pemakaian pembangunan partisipatif dari Mansour Fakih, dengan subteori Rusidi yang menggunakan empat dimensi partisipasi untuk melihat bentuk dominan partisipasi yang dilakukan oleh masyarakat di Nagari Situjuah Gadang. Berikut ini rangkuman hasil temuan selama proses Wawancara dengan informan penelitian. 


\section{Tabel 1.8. Rangkuman Hasil Penelitian}

\begin{tabular}{|c|c|}
\hline Teori & $\begin{array}{l}\text { Partisipasi Masyarakat dalam Pengelolaan Dana Desa di } \\
\text { Nagari Situjuah Gadang }\end{array}$ \\
\hline $\begin{array}{l}\text { Pembangunan } \\
\text { Partisipatif Mansour } \\
\text { Fakih }\end{array}$ & $\begin{array}{l}\text { - Pelaksanaan partisipasi masyarakat yang paling dominan hanya } \\
\text { sampai pada tingkat musyawarah jorong (pra perencanaan) } \\
\text { Masyarakat ditempatkan sebagai objek dalam pembangunan, } \\
\text { bukanlah sebagai subjek dalam pembangunan Nagari Situjuah } \\
\text { Gadang, dengan kata lain partisipasi yang dilakukan oleh } \\
\text { masyarakat pada dasarnya telah didikte oleh pemerintahan } \\
\text { nagari } \\
\text { Banyaknya dari masyarakat yang bersikap antipasti ketika } \\
\text { diadakannya musyawarah } \\
\text { Tingginya partisipasi masyarakat dalam Nagari Situjuah Gadang } \\
\text { yang kemudian turut mendukung nagari menjadi pengelola klinik } \\
\text { keuangan terbaik yang dijelaskan dalam temuan ini merupakan } \\
\text { partisipasi yang dilakukan oleh orang yang sama pada setiap } \\
\text { tahunnya, tidak ada pergiliran yang siginifikan dengan anggota } \\
\text { masyarakat yang lainnya. } \\
\text { Peran masyarakat ketika Nagari Situjuah Gadang menjadi klinik } \\
\text { keuangan terbaik, dominan hanya pada sumbangan tenaga dalam } \\
\text { melaksanakan pembangunan }\end{array}$ \\
\hline $\begin{array}{l}\text { Empat Dimensi } \\
\text { Partisipasi menurut } \\
\text { Rusidi Dimensi } \\
\text { Sumbangan Tenaga }\end{array}$ & $\begin{array}{l}\text { - Pada dimensi sumbangan tenaga masyarakat lebih cenderung } \\
\text { memiliki partisipasi yang tinggi, perihalnya dalam hal dimensi ini } \\
\text { tidak memerlukan biaya yang dikeluarkan oleh masyarakat dan } \\
\text { hanya perlu menyisihkan waktu. } \\
\text { Bentuk partisipasi masyarakat dalam dimensi tenaga ini dapat } \\
\text { berupa gotong-royong, baik secara terjadwal maupun suka-rela. } \\
\text { Gotong-royong suka-rela ini diartikan dalam bentuk pemberian } \\
\text { upah satu hari kerja dalam rentang waktu satu minggu kerja yang } \\
\text { dimiliki kepada nagari }\end{array}$ \\
\hline $\begin{array}{l}\text { Dimensi Sumbangan } \\
\text { Materi }\end{array}$ & $\begin{array}{l}\text { - Terdapatnya beberapa masyarakat yang memberikan bantuan } \\
\text { seperti bahan bangunan dan pembebasan lahan tanpa ganti rugi } \\
\text { - } \quad \text { Tetapi, dalam hal sumbangan materi ini sangat jarang ditemui }\end{array}$ \\
\hline
\end{tabular}




\begin{tabular}{|c|c|}
\hline $\begin{array}{l}\text { Dimensi Sumbangan } \\
\text { Ide/Gagasan }\end{array}$ & 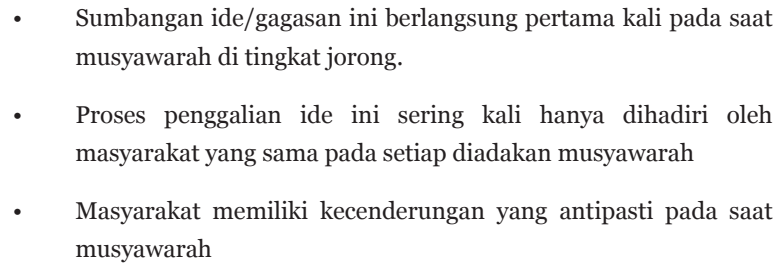 \\
\hline $\begin{array}{l}\text { Dimensi Memanfaatkan } \\
\text { dan Melaksanakan } \\
\text { Pembangunan }\end{array}$ & $\begin{array}{l}\text { - Adanya proses mengawasi dan memelihara fasilitas dan } \\
\text { pembangunan yang telah dilaksanakan. } \\
\text { Tetapi, dalam hal ini masyarakat memiliki kecenderungan } \\
\text { digerakkan terlebih dahulu oleh kepala jorong masing- } \\
\text { masing baru akan melakukan pemeliharaan dan perbaikan } \\
\text { pembangunan. } \\
\text { Dalam halnya pelaksanaan pembangunan masyarakat juga } \\
\text { memiliki kecenderungan untuk melakukan pembangunan yang } \\
\text { memberikan keuntungan kepada pribadi atau kelompoknya }\end{array}$ \\
\hline \multicolumn{2}{|c|}{$\begin{array}{l}\text { Temuan Baru Mengenai Partisipasi Masyarakat DalamPengelolaan Dana Desa di Nagari Situjuah } \\
\text { Gadang }\end{array}$} \\
\hline \multicolumn{2}{|c|}{$\begin{array}{l}\text { - Partisipasi masyarakat dalam pengelolaan dana desa di Nagari Situjuah Gadang lebih } \\
\text { dominan dalam hal musyawarah pra perencanaan di tingkat jorong } \\
\text { - } \quad \text { Keikutsertaan masyarakat dalam menyukseskan Nagari Situjuah Gadang menjadi klinik } \\
\text { keuangan terbaik pada tahun } 2018 \text { sebagian besar dalam hal sumbangan tenaga }\end{array}$} \\
\hline \multicolumn{2}{|c|}{$\begin{array}{l}\text { Besarnya dominansi dari dimensi ini berkaitan dengan minimnya pengetahuan, pendidikan, } \\
\text { dan ekonomi yang dimiliki oleh masyarakat }\end{array}$} \\
\hline \multicolumn{2}{|c|}{$\begin{array}{l}\text { Berbeda dengan temuan terda } \\
\text { masyarakat dalam ekonomi ak } \\
\text { dalam pengelolaan dana desa }\end{array}$} \\
\hline Di Nagari Situjua & ang sendiri tidak adanya pengaruh atas pendidikan dan ekonomi atas \\
\hline
\end{tabular}

Sumber: Dikelola oleh Peneliti Tahun 2021 Berdasarkan Penelitian Lapangan di Nagari Situjuah Gadang 


\section{KESIMPULAN}

Fokus dari hasil penelitian yang ditemukan di lapangan bahwasanya partisipasi masyarakat dalam pengelolaan dana desa di Nagari Situjuah Gadang cenderung menempatkan masyarakat sebagai objek dari pembangunan, bukanlah sebagai subjek dari pembangunan. Masyarakat lebih cenderung untuk menerima hasil dari pembangunan yang dilakukan dan direncanakan meskipun telah ikut dalam musyawarah. Tetapi, keikutsertaan masyarakat relatif tidak mengeluarkan ide/gagasan yang digunakan dalam proses tahapan pembangunan dan penggunaan dana desa selanjutnya.

Sejalan dengan hasil temuan tersebut, terdapatnya klinik keuangan di Nagari Situjuah Gadang yang berperan dalam melakukan kontrol atas pengelolaan dana desa yang melibatkan masyarakat dalam beberapa bentuk partisipasi, pertama yaitu dimensi ide/gagasan, dimana dalam partisipasi masyarakat di Nagari Situjuah Gadang ini akan dimulai dengan cara musyawarah dari tingkatan terendah atau jorong hingga ke nagari. Kedua, yaitu dalam dimensi sumbangan tenaga, dalam hal ini masyarakat akan bergotong-royong secara sukarela. Ketiga, yaitu sumbangan materil, dapat berupa bentuk bantuan pasir, semen, kerikil, dan bahan 
lainnya yang diperlukan dalam pembangunan yang dilakukan. Keempat, yaitu dimensi memanfaatkan dan melaksanakan pelayanan dan pembangunan yang telah dilaksanakan, dalam hal ini masyarakat biasanya memelihara dan mendayagunakan pembangunan yang telah ada.

Berdasarkan keempat dimensi yang telah dipaparkan dan dianalisis berdasarkan temuan lapangan, keempat dimensi partisipasi masyarakat tersebut merupakan basis yang dapat menentukan kinerja mekanisme klinik keuangan yang ada di Nagari Situjuah Gadang dapat berjalan dengan baik. Apabila partisipasi masyarakat dalam setiap tahapan dan kontrol pemerintah terhadap jalannya pengelolaan dana desa mumpuni, maka akan terdapat keseinambungan dalam proses pengelolaan dana desa, partisipasi, dan klinik keuangan yang dijalankan. Tetapi, jika partisipasi masyarakat dalam setiap tahapan tidak terlaksana dengan baik (pengelolaan dana desa minim akan partisipasi masyarakat), maka hal ini akan menyebabkan klinik keuangan tidak berjalan. Sebab, pemerintah tidak lagi memiliki kontrol dalam pemantauan jalannya proses pengelolaan dana desa tersebut. 


\section{REFERENSI}

\section{BUKU}

Fakih, Mansour. (2019). Sesat Pikir Teori Pembangunan Dan Globalisasi. Yogyakarta: Insist Press.

Idrus, M. (2019). Metode Penelitian Ilmu Sosial. Yogyakarta: Erlangga.

Kuncoro, M. (2018). Perencanaan Pembangunan Daerah (Teori\& Aplikasi). Jakarta: PT Gramedia Pustaka Utama.

Solekhan, M. (2014). Penyelenggaraan Pemerintahan Desa Berbasis Partisipasi Masyarakat. Malang: Setara Press.

Sugiyono. (2012). Metode Penelitian Kuantitatif Kualitatif dan $R \& D$. Bandung: Alfabeta.

\section{JURNAL}

Adenansi, D., M. Zainuddin, and B. Rusyidi. (2015). PartisipasiMasyarakatdalamProgramPemberdayaan Masyarakat PNPM Mandiri. Prosiding Penelitian dan Pengabdian Kepada Masyarakat, 2 (3), 347353. 
Arifiani, T. A., and S. Sjaf. (2018). Analisis Respon Masyarakat terhadap Pengelolaan Dana Desa untuk Pembangunan Pedesaan. Jurnal Sains Komunikasi dan Pengembangan Masyarakat [JSKPM], 2 (3), 317-332.

Kusrini N, S. Amanah , A. Fatchiya. (2013). Sikap Masyarakat terhadap Pengembangan Desa Pesisir Tangguh di Teluknaga, Tangerang, Banten. Jurnal Sosio Konsepia, 3 (1), 287-30o.

Listyawati, D., Sarmiati, and Asmawi. (2019). Komunikasi Perangkat Nagari dan Partisipasi Masyarakat dalam Pengelolaan Dana Desa. JISPO, 9 (1), 97-106.

Melis, Abd Azis Muthalib and Apoda. (2016). Analisis Partisipasi Masyarakat dalam Pembangunan Desa (Studi di Desa Wawolesea Kecamatan Lasolo Kabupaten Konawe Utara). Jurnal Ekonomi, 1 (1), 99-105.

Ritantri. (2015). Partisipasi Masyarakat Desa dalam Membangun Desa di Desa Sandeley Kecamatan Kuaro Kabupaten Paser. eJournal Ilmu Pemerintahan, (3) $1,164-176$. 


\section{SURAT KABAR ONLINE}

Dekade, Pos. (2019). Dana Desa ditambah 15 Milyar Lima Puluh Kota Lakukan Pengawasan Melalui Klinik Keuangan. Dekadepos. Retrieved from https://www. dekadepos.com/2019/01/29/dana-desa-ditambah15-milyar-limapuluh-kota-lakukan-pengawasanmelalui-klinik-keuangan/.

Jurnal, Sumbar. (2019). Lima Puluh Kota Dapat Alokasi Dana Desa Rp 75 Milyar. Jurnal Sumbar. Retrieved From http://jurnalsumbar.com/2019/01/2019limapuluh-kota-dapat-alokasi-dana-desa-rp75miliar/.

Berita, Editor. (2017). Irfendi Arbi Luncurkan Klinik Keuangan Nagari. Portal Berita Editor. Retrieved From https://www.portalberitaeditor.com/18171-2.

\section{WEBSITE}

Humas DJPK, Retrieved from http://www.djpk.kemenkeu. go.id/?p=5747.

BPS Kabupaten Lima Puluh Kota, Situjuah Limo Nagari Dalam Angka 2019, Retrieved from https://limapuluhkotakab.bps.go.id/ publication/2019/09/26/. 
Fatizah Rahmi, Asrinaldi, Indah Adi Putri 